\title{
The silent victims of humanitarian crises and livelihood (in)security: A case study among migrants in two Chadian towns
}

Syntyche Nakar Djindil

Wageningen University, Law and Governance Group The Netherlands syntyche.djindilnakar@wur.nl

Mirjam de Bruijn Africa Studies Centre, Leiden The Netherlands bruijnm@ascleiden.nl

\section{ABSTRACT}

Once a humanitarian disaster receives coverage in the global media, the international community usually mobilises to reduce the most severe consequences. However people in Chad are experiencing endemic crises that are detached from specific triggers, and they are not receiving any international assistance to help relieve the hardships they face. This study involves 111 migrant households from central Chad that, as a result of war and drought, have lost everything and now have to live in squatter areas of N'Djamena and Mongo, facing uncertainty and threats while negotiating their livelihoods. Qualitative and quantitative methods have been combined in this study to reveal the intriguing story of their daily lives in the face of complex and endemic crises. Anthropometric and health data were generated to determine the nutritional status of mothers and their children under five. Life histories, in-depth interviews and participatory observation allowed the researchers to capture the negotiation strategies they use to access food and shelter, their experiences of food insecurity and sanitary vulnerability, and the consequences these have on daily life. Results indicate that $62 \%$ of households were female headed, there were high rates of acute (40-50\%) and chronic (35-40\%) malnutrition and 46\% of the mothers were underweight and anaemic. Infant mortality rates were also high at $30 \%-42 \%$ and $97 \%$ of the children had had incomplete or no vaccinations. No households had access to clean water, sanitation or public-health services. Endemic corruption and abuse by the authorities were identified as major sources of day-to-day insecurity. These migrants were not expecting any improvement in their livelihoods in the foreseeable future and saw these miserable conditions as normal.

\section{KEYWORDS}

Urban-migration, silent victims, humanitarian crisis, Livelihood, Chad 
Compared to before, I would say that my life is better now. I have a house and a bicycle, and now my daily preoccupation is food and caring for my family. In 1984, drought and especially rebel activities ruined my family and our village's crops and stock. We had nothing to eat and the prospects for the village were bleak, there was no rain, and the soil was dry... I decided to leave the village to go to Mongo to look for food, promising to return soon. When I arrived in Mongo, the situation was horrendous. Many people had arrived from different villages because of insecurity and hunger.. I could have waited a month to be registered as a refugee and live in the camp and receive daily food. That was not my aim and was not a solution for me. I had to find a way to feed my family... I could not return to the village with nothing so I decided to continue to N'Djamena. The first year there was difficult. I lived on the streets of Djamalbar with other people in need. Some nights soldiers ran around the city and caught men and sent them to fight, so we had to find ways to hide somewhere when the soldiers' 4 $x 4 s$ passed. It was a very hard time but a few months later I found a job as a carrier. It was hard to earn even FCFA 1000 a day but I decided to take the work and carry ten bags of $100 \mathrm{~kg}$ a day (each $b a g=$ FCFA 100). With the money, I bought this land. At that time it was cheap and I moved my family from the village to here.

-Hassan, 44 years old, Nguéli, a marginal neighbourhood in N'Djamena, January 2005.

\section{Introduction}

Like Hassan, many victims of the crises in Chad have to eke out a living by negotiating uncertainties and threats. These people are to be found everywhere: in the cities, on the margins of cities and in villages and they are facing similar crises to those that have typically struck Central Africa over the last forty years, namely war, drought and economic insecurity. These crises condition the daily lives of many in Chad who remain invisible, have no channel to voice their worries, and few choices. Survival under such circumstances becomes a gamble as they juggle insecurities and worry every day about whether they will have enough food to feed their families.

These stories should be situated in the regional context of Central Africa, which has been the scene of crises of diverse kinds and origins that have now become endemic and chronic. This is the case in Chad where wars and insecurity, drought, ecological degradation, famine and epidemics have coloured the history and livelihoods of the population. Since the 1960s, the country has been facing instability. Social cohesion has always been fragile and armed conflicts are easily triggered; political, economic and institutional governance is weak and mostly corrupt; and insecurity and political oppression continue to hamper the development of civil society (Azevedo, 1998; Miles, 1995; De Bruijn \& Van Dijk, 2007a; De Bruijn \& Van Dijk, 2008; Van Dijk, 2007, International Crisis Group, 2006). As a consequence, living conditions remain precarious and can deteriorate at any time. Chad is regularly classified among the world's ten least-developed countries according to the Human Development Index (Human Development Reports, UNDP, 1990-2008). Despite recent oil production, which has increased GNP 
and other economic indicators, human and social development, including health indicators, have worsened and war is once again destabilising the country. Child malnutrition and mortality rates remain high, access to social services, drinking water and sanitation are low while the number of female-headed households is increasing due to the fighting, epidemics and labour migration (WGI, 2008; OECD, 2007; Djindil et al., 2007; USAID, 2008). Generations have been and will continue to be affected in their chances and moral and intellectual development. They are condemned to be born, live and give birth in situations of chronic vulnerability, insecurity and bad governance.

In addition to the civil war in 1979, the droughts of the mid-1980s and the recent Darfur crisis have attracted massive international humanitarian aid. However, most Chadians are experiencing endemic crises that are detached from specific triggers and these tend not to receive international attention. The rest of the world knows little about the 'silent disasters' in Chad. Recent research has led to a better understanding of the multiple experiences of civil war in the rural and urban areas in Chad that are renowned for their persistent insecurity and instability (De Bruijn \& Van Dijk, 2007b; Dickow, 2005; Eriksson \& Hagströmer, 2005). These studies are valuable in the way they highlight the political and historical aspects of generalized crises in Chad but they do not provide insight into the conditions the forgotten victims face on a daily basis. This article attempts to show the lives of these people by analyzing the livelihood security of various migrant families in urban environments in Chad. Livelihood security is understood as the degree of access to resources for survival and includes the physical, ecological, moral, socio-economic, cultural and political aspects of a minimum set of entitlements to maintain a livelihood. Vulnerable and poor households on the margins of Chadian society experience extreme insecurity and uncertainty and engage in interpersonal and community-wide 'manoeuvres' to create and maintain their livelihoods.

The livelihood activities that people pursue are based on the quantity and quality of the assets to which they have access. Assets can be of various types (social, economic, physical, natural and human) and be privately or publicly held. Different households have different levels of access to assets, influencing their ability to prevent, mitigate or cope with shocks. The types of risks that form a threat to people's food security are also a function of their livelihoods (Chambers \& Conway, 1992; Devereux, 2001).

To understand their position, this study chose to combine qualitative and quantitative research methods. Qualitative analysis and methodology lead to narrative articles that offer insight into the negotiation for resources for survival of these so-called victims (e.g. De Bruijn \& Djindil, 2006; De Bruijn, 2007 on street children in N'Djamena). The literature shows how, in unfavourable circumstances, people develop their own lives in creative ways (Essed et al., 2005). This article focuses on people who have fled crises and moved to a city where they are eking out a living on the outskirts of the city. The capacity of poor people to negotiate access to resources, assets and claims (i.e. to realize entitlements) determines their level of livelihood security (Ribot \& Peluso, 2003; De Bruijn 2007; De Bruijn \& Djindil, 2006). Our study investigates the living conditions and experiences of people who have migrated to two major cities: Mongo, the capital of the Guera region, and Chad's capital, N'Djamena, that is situated 
$500 \mathrm{~km}$ to the west. We specifically examine how these people negotiate access to basic needs (health, housing, food, drinking water) while coping with chronic civil insecurity, oppression and high levels of stress. Such understanding could indeed contribute to defining suitable assistance in an endemic crisis-situation and ultimately, to improve long-term effectiveness of humanitarian assistance programs. Disturbance of livelihood security can destabilize households' food security affecting the physical and psychological status of people and the development of physical and mental capacities of their children. These aspects were captured by measuring the nutritional and recording the life histories of their families.

\section{Methodology}

\section{Fieldwork}

From November 2002 to April 2003, anthropological, sociological and anthropometric data were collected among migrants from the Guera region, who were living in the urban peripheries of N'Djamena and in Secteur 4, a squatter area in Mongo. In N'Djamena, most of the migrants lived in urban areas where they could access unoccupied land. As a first step, we explored some of these districts to identify migrants from the Guera and assess the feasibility of future research among their communities. It was not easy to establish contact: distrust, verbal abuse and an almost systematic refusal by most interviewees clearly showed that promising research was not going to be feasible. Nevertheless, the inhabitants of two districts - Diguel Zafaye and Nguéli - were more favourably disposed to our requests. Here we encountered 33 and 30 households respectively that originated from the same villages in the Guera and who were willing to collaborate with our research team and help us establish additional contacts within their community. In Mongo, most of the displaced people live in the Secteur 4 neighbourhood where we worked with 48 households from different ethnic groups.

\section{Livelibood and food insecurity}

To address our main topic of characterizing livelihood strategies, we conducted a series of interviews on life histories with men and women individually and also in groups, addressing their experiences during different crises before migration and the strategies they had employed since leaving their village to obtain accommodation and generate new livelihoods in a context of insecurity. Some of the people, especially the men, refused to talk about their experiences during the war and about issues related to State policy reflecting a general feeling of fear and trauma. However, they could explain their own strategies and the tactics they had employed and developed to create a new home and livelihood. The women were more open and provided detailed narratives.

Disturbed economic, cultural and social relationships can destabilise households' access to and quality of food, affecting the physical and psychological status of adult people and the development of physical and mental capacities of their children. These aspects were captured by measuring the nutritional status of mothers and their children under five, and recording the life histories of their families. To estimate the level of food insecurity of households our empirical work focused on two key issues in each household: the availability of food and the possibilities for accessing food. For children under five, we were also interested in basic information on 
breastfeeding and methods of weaning. Food security exists when all people at all times, have physical and economic access to sufficient, safe and nutritious food to meet their dietary needs and food preferences for an active and healthy life" (FAO, 1996). This definition integrates stability, access to food, availability of nutritionally adequate food and the biological utilization of food.

Socio-economic and demographic data were generated for all the households in our sampling, in addition to basic estimates of the household's economy. Potential determinants of social vulnerability and sources of inequity were also assessed: marital status, educational status, occupation, the number of children and dependants in each household, the main sources of income, access to healthcare, schooling and clean drinking water, and participation in social networks.

\section{Health and nutritional status of children and their mothers}

Women and children are the most vulnerable group among migrants. . We used structured questionnaires to obtain demographic and health-related information about children and their mothers and made local calendars to estimate the children's ages. Anthropometric measurements were realised by measuring the height and weight of all children between 6 and 59 months in each household included in the survey. Epi-info software was applied to calculate Z-score indices in terms of height for age (HAZ for stunting) and weight for height (WHZ for wasting). Z-score values were interpreted in accordance with NCHS standards (National Centre for Health Statistics) that have been adopted by the WHO and the CDC as a method of measuring children's nutritional status (WHO, 1995). Accordingly, we defined -2 Standard Deviations as the cut-off point for malnutrition. We assessed the mothers' nutritional status by measuring their body weight, height and haemoglobin levels. Mothers were classified according to their Body Mass Index $\left(\mathrm{BMI}=\right.$ weight in $\mathrm{kg}$ divided by height in $\left.\mathrm{m}^{2}\right)$ in three groups: Underweight $\left(\mathrm{BMI}<18.5 \mathrm{~kg} / \mathrm{m}^{2}\right)$, normal $(18.5<\mathrm{BMI}<24.5)$ and overweight $\left(\mathrm{BMI}>25 \mathrm{~kg} / \mathrm{m}^{2}\right)$ according to $\mathrm{WHO}$ standards. Haemoglobin levels were interpreted according to $\mathrm{WHO}$ thresholds: Mild anaemia $(10<=\mathrm{Hb}<12 \mathrm{~g} / \mathrm{dl})$, moderate anaemia $(7<=\mathrm{Hb}<10 \mathrm{~g} / \mathrm{dl})$ and severe anaemia $(\mathrm{Hb}<7 \mathrm{~g} / \mathrm{dl})$. The main results of the study are presented in the following sections, with an introduction to each area followed by an illustration of aspects of the specific social, economic and physical environment of some subjects' life histories, their current living conditions and accommodation, and details about how they face everyday life. Food insecurity and vulnerability are seen in the nutrition and health status of the mothers and children, life-historyrelated social disruption and psychological distress.

\section{Crises in Chad: Translation to the study of urban peripheries}

Before we delve into the case studies, let us first explain what our interviews revealed about the complexity of the crises people are living through in Chad. The juxtaposition and analysis of migrants' different viewpoints allow for a gradual reconstruction of the history of war and drought in Chad. From the migrant-households $(\mathrm{n}=111)$ in our sample, $73 \%$ left their villages between 1970 and the 1990s. Those decades were characterized by three major events in Chad: the Sahelian droughts of 1973-74 and 1980-85, the civil war in 1979, and the turmoil that preceded the accession to power of Hissein Habré in 1982 and Idriss Deby in 1990. Ad- 
ditional transitional crises and repression were targeted at the Hadjaray communities in 1987 under Hissein Habré. After the 1965 peasant revolt in Mangalmé and similar rebellions in mid-1990, different groups of rebels chose specific areas of the Guera to recruit soldiers and for strategic mountain hideouts. The rebels, or bandits as they were known locally, caused tremendous socio-economic upheaval and psychological damage in the villages. Villagers were caught between the government and the rebels, both of whom accused them of complicity, and the degradation of living conditions in these villages forced many to leave their homes. The Red Cross accompanied some of the villagers to nearby towns to find food and healthcare. Most have never returned home. Migration is a response to insecurity and violence by people who live under political and environmental pressure. Gallais described mobility as a typical 'Sahelian condition' but in Chad, it is not only Sahelian conditions that are pushing people to migrate but also insecurity (Gallais, 1975). The presence of so many Hadjaray in N'Djamena is a response to insecurity and various forms of violence. As many attest, droughts are a natural phenomenon in the Sahel to which people are accustomed, but rebel violence and other threats demand different coping strategies and the management of even normal crises often then becomes impossible. The ultimate solution is to leave. But how do people survive when they leave? Our research in N'Djamena and Mongo reveals part of this story.

\title{
Diguel Hadjaray: A neighbourhood on the outskirts of N'Djamena
}

\begin{abstract}
I am the leader of the Hadjaray in Diguel Zafaye. In my village, I worked as a cook for the Sisters of the Catholic Church. After 1976, rebel attacks became frequent, the sisters felt threatened and the situation got worse and worse. The rebels mistreated everybody in the village. They forced the sisters to leave the Guera and go to N'Djamena. This is how I arrived in N'Djamena in 1978. I lived with the sisters and later my wife and children followed me. I was going to return but it was impossible. In my region and everywhere in Chad rebel movements became more violent, and the civil war started in N'Djamena. The sisters went back to their own country (France) and I had to find other work to feed my family. I have been living here for nine years now. My situation is fine and I hope it will remain so. Since I left the village, this is the first time I have been living in a fixed place for so long. Before that, I lived in the neighbourhoods of Kabalaye, Ardeb-Djoumal and Sabangali. I was like a nomad and my housing depended on the type of job I had. The majority of my compatriots experience this nomadic life.
\end{abstract}

Souleyman Azarak, Diguel, May 2003

Situated in the north of the city, Diguel is one of biggest squatter areas in N'Djamena. Diguel is divided into squares bearing the names of ethnic groups or the activities of the inhabitants. Diguel Zafaye, where we conducted our study, is on the edge of the district and we were able to meet different ethnic groups from the Guera, commonly called the Hadjaray ('rock' in Arabic, referring to the Guera's mountainous terrain). The people, mostly Dangaliat from Korlongo, had been forced for various reasons (war, rebel attacks, drought, famine or conflict) to leave their villages. Souleyman, the leader of the Hadjaray in Diguel Zafaye, is Dangaliat and the person who found out how to access (free) space in Diguel. The name Diguel Hadjaray was officially recognised in 1994 by the Department of Cadastres and 33 households (15 were fe- 
male headed) in this neighbourhood from the Dangaliat ethnic group participated in our study. The average age at which these migrants came to N'Djamena was nineteen: $6 \%$ arrived before 1980, 76\% between 1980 and 1990, and 18\% between 1990 and 2003. The majority $(80 \%)$ had left their village for two reasons - drought and frequent rebel attacks. As a result of the rebels' activities, they had lost their belongings and any means they could have used to cope. Most of them had no option other than to leave.

Until 1990, occupying land in Diguel Zafaye was arbitrary and virtually free. Sometimes the quarter chief would authorise people to use it for housing and agriculture in exchange for a little money. Souleyman Azarak (see above) was the first Hadjaray to find land in Diguel Zafaye and he then informed other Dangaliat in the city about the possibilities there. In our sample, 27 of the households had received such information from him and taken the opportunity to access land and settle in Diguel, thus escaping some of the pressures of life in the city itself. In 1994, the Land Registry introduced registration regulations and any inhabitant without official documentation certifying his/her property was excluded or had to pay a significant sum of money for it. The land market around Diguel has been expanding, as has the public authorities' abuse of inhabitants by over-enforcing official procedures. Souleyman Azarak continues the interview on how Diguel Hadjaray was created:

In 1994 the Service of the Land Registers noted a strong concentration of Hadjaray in this part of Diguel, so they decided to recognise the name 'Diguel Hadjaray'. I was born in 1951 in Korlongo in the Guera region. I have seven children. When I arrived in N'Djamena, I was like a nomad, I had no fixed place to live and my home depended on my work. After losing my job with the sisters, I worked as a guard but people did not accept me as a guard with a large family and my salary was not enough to rent a house. Therefore I decided to find a place outside the city. I searched for months and, finally, one of my friends informed me about a possibility on the edge of Diguel. I started with a garden and later I built a house and moved my family. Now the community of Hadjaray in Diguel is big, which offers security. The garden is profitable but requires a lot of investment: the soil is poor and water is a big problem. Now, I have a motor pump but the quantity of water depends on rainfall and the people on the other side who use the same source.

In spite of the difficult conditions in N'Djamena, i.e. land scarcity, low soil fertility and poor rainfall, the Hadjaray have managed to reproduce village life in Diguel Zafaye. Working the land remains their main survival strategy and $95 \%$ of the households cultivate food crops as their main income strategy. The urban influence on their lifestyle is that women are able to engage in petty trading (mainly selling sugar, tea, okra, etc.) and the men can find manual work. Physically too, Diguel is like a village: all the houses are built of clay and the fields are located around the houses.

Households averaging four persons are considered to be poor, as can be seen from the nutritional and health conditions of the mothers and children: Their main dish is porridge with different kinds of sauces, usually gombo ${ }^{I}$ : the consumption of dairy products and protein is rare. 
The frequency of daily meals varies between one and two, and only 13 households regularly had two meals a day. Twenty-two of the 36 children between six and 59 months were acutely malnourished with an average weight for height below -2 . Seventeen were suffering from chronic malnutrition (height for age Z-scores under -2) which results from inadequate food intake over a long period of time. There is no appropriate weaning of children: they are weaned early and then share the meals with adults. Only seven children were fully immunised. Twentynine of the women had haemoglobin levels less than $12 \mathrm{~g} / \mathrm{dl}$ and sixteen were severely affected, with levels of haemoglobin below $7 \mathrm{~g} / \mathrm{dl}$. These results are consistent with being underweight. Only nine of the 33 women had a normal BMI $\left(18.5-25 \mathrm{~kg} / \mathrm{m}^{2}\right)$, and the remainder $(\mathrm{n}=24)$ were underweight, with 13 severely underweight.

These indicators reflect the level of physical suffering. Infant mortality is quite high, with two deaths for every five births. This could be related to problems during pregnancy, low birth weights, inappropriate weaning and particularly to inadequate and insufficient levels of food intake. Only six households confirmed that they had sufficient resources to secure their food requirements. Of these, four have gardens and pumps for watering them, and are thus able to produce vegetables to sell during the year. Seven women who engage in sharecropping are more vulnerable and their low level of productivity does not allow them to pay the owner of the land they cultivate.

Since 2002, Diguel has been included in the city's expansion plans and many new buildings are starting to go up. As a result, there are now some private installations for tap water and this has allowed inhabitants temporary access to drinking water until the building work is finished. This construction activity in Diguel has provided manual work for the men and opportunities for small businesses (selling donuts, peanuts, sugar and tea) for the women. These activities contribute to the food security of 21 households, but unfortunately this will only be for a short period of time.

The city's development is threatening those who do not have official documents for the land they occupy. The regularisation of boundaries remains a serious problem. Exclusions are imminent and this has increased fears among the migrants. Souleyman Azarak continues as follows:

Of course, I am the leader of the Hadjaray but it is difficult to manage all their problems. Land problems are especially sensitive and politicised, I must be careful to maintain my own properties and my social relationships. There are rich men who increasingly want to acquire land here, and they are trying to impose themselves in all kinds of ways. I am really upset. Some of my compatriots are accusing me of being an accomplice and helping the rich men and the chief of land, but only God knows what kind of pressure I have to bear. I wonder every day about my future relationship with my compatriots.

Schooling was beyond the financial means of $97 \%$ of the households and access to healthcare was also problematic. The nearest health centre is about $5 \mathrm{~km}$ away, the cost of treatment is between FCFA 200 and FCFA 500 (which is equal to $1 \mathrm{~kg}$ of rice), and the quality of service was sometimes questionable. Women delivered their babies at home with the assistance of 
older women in the community, and all of them were in favour of traditional methods and networks of choukous (traditional healers). The reaction of Halima Kinger who lives in Diguel Zafaye is cited below and highlights the local distrust of the public health centre in N'Djamena:

I do not go to the hospital anymore, and I would never advise people to go there. When I was in my village, I always thought that life in the city was better because it gave opportunities for healthcare. Now I am here and I see the reality: A hospital is not a place for Miskines (the poor in local Arabic).You still need a lot of money to go there. First, you have to travel a long way to get there. It is better to go by bus but when you are hard up you have to walk. Once at the hospital, you have to buy the carnet de sante that allows you access to a consultation. If you know someone or have akalgoro (money for a tip) you can easily avoid a long wait. Contact with the doctor depends upon his mood ... Most of the time, you waste money and time and don't get properly treated. With choukous (unlicensed medical practitioners) there is no problem: for headaches, we pay FCFA 25, for malaria FCFA 100 and they are helpful... I do not think that choukous' treatment involves danger. That is just bad publicity: If there has been a case of poisoning or a death with choukous that is the will of Allah.

Although Diguel is an integral part of N'Djamena, life there is as it is in the rural areas. From day to day, residents invest in efforts to rebuild their livelihoods, but the possibilities are limited. The political and socio-economic environment does not offer opportunities to improve one's living conditions and it leaves people with a perpetual sense of anxiety that affects their physical and psychological well-being. Insufficient and unstable productivity causes food insecurity. Since their survival is based on culture and living space, the disruption of these opportunities deeply disturbs the dynamics of the social network and generates feelings of depression and stress.

\section{Nguéli: A neighbourhood in N'Djamena on the road to Cameroon}

Nguéli is located on the southwestern outskirts of N'Djamena on the road that leads to the bridge over the Logone River on the border with Cameroon. Nguéli is part of the $9^{\text {th }}$ arrondissement and is inhabited by different ethnic groups. During the civil war in Chad from 1979-82, many houses in the area were either destroyed or occupied by the army or rebels and a lot of people fled to Cameroon, some choosing not to return even after the fighting was over. Some of the people wanted to live close to Kousseri, the Cameroonian city at the other side of the bridge, their new centre of activity for income-generating activities and social networking and this resulted in the expansion of Nguéli, which also grew following the arrival of thousands of Congolese refugees in 2003. Nguéli is the transfer site of goods between Nigeria, Cameroon and Chad and a place where many military personnel spend their time. It was not easy for us as researchers to access this neighbourhood because of people's distrust and the dangers of a potentially criminal environment. Fortunately with the help of Fottor Moussa Melé, the son of the former chief of Baro, we were able to win the trust of the Hadjaray community, especially the Migami of Nguéli.

Nguéli appears chaotic and it is difficult to establish the boundaries round each house. There are no paths; people walk between the clay houses to get to their own homes and to reach the 
river and the big avenue that connects Nguéli and the bridge. There are no latrines or clean water and no drainage system. As in Diguel, Hadjaray groups live together. We worked with 30 Migami households, of which 12 were female headed: 5\% had come to N'Djamena before 1980, 83\% between 1980 and 1990 and 12\% between 1990 and 2003. The majority had left the Guera between 1980 and 1990 because of famine, insecurity and political repression.

The district of Nguéli offers livelihood opportunities for illegal business activities and legal work (gardening, growing rice, domestic work, motorbike taxis, laundry) both in N'Djamena and Kousseri. The majority of the women walk through the neighbourhoods to pick savonier leaves that form the basis of Hadjaray sauces and make them feel as though they are still in the Guera. Nguéli has health centres and schools nearby but according to the inhabitants and our own observations, being able to access these resources depends on the political regime and social manoeuvring. The situation in Nguéli is in this respect very different from Diguel where politics is limited to housing. When Hissein Habré came to power in 1982, the military invaded all Nguéli's economic and social structures. The situation has since deteriorated considerably: the trafficking of goods is dangerous and the military constantly abuse and torture people. Twenty-five of the women in our sample confirmed having been involved in this business and have since lost their financial capital.

Another employment possibility for women in N'Djamena and Kousseri is providing a laundry service. Women are paid either in cash or in kind (soap, sugar, tea, clothes) and also receive cereal bran which has allowed some of them to start small businesses. This cereal bran is often used to produce the (illegal) distilled traditional liquor called Argui, which sells well. Since 1992 with the introduction of hulling machines, this work is no longer lucrative for Hadjaray women.

Meeting in groups in Nguéli is not possible because of the omnipresence of the military. The transportation of all goods is suspected to be fraudulent and the people involved can easily get into trouble. Kaltouma describes how people are treated by the military in Nguéli:

You are allowed to carry things from N'Djamena to Nguéli but everything that goes from Nguéli towards the city is suspected of being secretly trafficked. There are karankaran and bogo-bogo II everywhere; they can beat you to death. Look at the scars I have on my right shoulder. They are the result of beatings by the douanier mobile. Last year, on my way to Mardjandafak where my little sister was expecting a child, I had some soap and clothes in my bag. The douanier mobile arrested me at the bridge. While I was trying to explain something, one of them beat me on my shoulder treating me as liar. They took my bag with everything inside and do the same to other people. If someone tries to run or resist, they could easily use a gun or even kill him. I returned home with difficulty... They are the chiefs and lawyers, so what else can we do than bear it? (Kaltouma, Nguéli, January 2005)

Gardening remains the only certain livelihood as it can generate money and give women the opportunity to focus on the vegetable market. However even with gardening there are many conflicts and its management has become difficult. Some people use their political networks to 
claim ownership of land but the military have claimed the fertile land along the river and soldiers use manipulation and sometimes violence to enforce their goals.

The women in our research sample testified that life had become more difficult and expensive. For 18 households, their accommodation was guaranteed and those who had arrived before 1980 had had the opportunity to purchase land although it has now become too expensive to do so. Households consist of an average of 4.5 individuals and sharing rooms is normal. Alcoholism and sexual promiscuity among men are increasingly common in the community and women prefer to divorce their husbands rather than risk AIDS, which is also increasingly prevalent in the area.

Adolescents are employed in transport and the world of motorbikes as apprentices and mechanics. In some cases, these activities are beneficial to the family but often the youth become street boys (De Bruijn \& Djindil, 2006). Girls get married at an early age or they become prostitutes. Pregnancies outside of marriage are frequent and this weighs heavily on the welfare of households. There are more and more cases of sexually transmitted diseases among young people, teenage pregnancies are common and the rates of maternal and infant mortality are high, with one child in every three dying before they reach the age of five. The average age of a woman's first pregnancy is just 13.5 .

Out of the 40 children aged between six and 59 months in our sample, 24 were suffering from acute malnutrition (weight for height Z-scores under -2), 16 were stunted (height for age Zscores under -2). Among these children, 20 had been fully immunized due to the proximity of a health centre and the motivation of the mothers themselves. Eighteen of mothers were underweight with a BMI below $18.5 \mathrm{~kg} / \mathrm{m}^{2}$ and nine were severely underweight. Haemoglobin levels showed that 25 of the mothers were anaemic with an $\mathrm{Hb}$ rate less than $12 \mathrm{~g} / \mathrm{dl}$, and 13 were below $7 \mathrm{~g} / \mathrm{dl}$. Their consumption of protein, especially meat, was quite high and 20 of the households had two meals a day. These results are inconsistent with the nutritional status of the mothers and children and the levels of anaemia among the mothers. This led us to wonder about the quality of the protein in the food being consumed.

The national livestock market is held twice a week in Nguéli. All the animals that cannot cross the bridge to go to Cameroon due to illness are slaughtered and the meat is sold at local markets and a lot of people from N'Djamena come often to buy cheap meat in Nguéli. In the evenings when the meat is in a state of decay, prices drop and the poor wait until then to buy their meat. Ten of the households surveyed in Nguéli had a household member who worked for a butcher and received free meat. Drinking water comes from wells and the river with all the problems of contamination this entails as it is used for washing, drinking and cooking. Thirteen households in the survey purchased water from taps (20 litres for FCFA 50). There is no municipal sewage or garbage collection, homes are close together and only the inhabitants know the limits of their concessions. Candles are used for lighting at night.

The poor living conditions result in risks and high levels of violence, which makes leading a normal life impossible. There is constant pressure from (false and real) state agents who are allowed to enter concessions to search for evidence of fraud and to threaten the families living 
there. After experiencing confrontations with customs officers who had destroyed all their goods, 22 of the women in our study abandoned trading in manufactured goods and limited themselves to small businesses selling local products within their own social circle. This can earn them an average of FCFA 650 a week, which does not even meet the daily requirements of one person. To help themselves, women organised tontines, to which they contribute FCFA 200 per week and which will be returned to them in turn. This system has also been affected by the deteriorating socio-economic conditions. In the past, women saved FCFA 300 a week but now many of them are unable to earn even this amount so they have decided to reduce the contribution to provide an opportunity for the poorest to start or maintain a small business. This is the case of Khamissa, whose husband appears physically fit but is psychologically unwell. During the war, he was a soldier in Hissein Habrés army but the experience turned him into an antisocial and morally corrupt person. People in the community know that he committed atrocities involving their relatives and he no longer has a place either among the migrants or in his own village. It therefore falls to his wife Khamissa to do everything possible to ensure her family's survival. She was one of the poorest women in the community and for financial reasons had married off their twelve-year-old daughter to a sixty-year-old man who already had two wives. Khamissa explains:

I am the mother of three children. The charcoal trading I do at home is the most secure trade that I can do today. I must be careful to maintain my minimum. It is my vital capital, and if I sell sugar or soap, I risk losing everything. Similarly, I do not dare to sell on the side of the highway although I would have more customers. The council will charge me for the place where I sit and the customs will not hesitate to confiscate my charcoal. All the neighbours know I sell charcoal here, I earn about FCFA 300, sometimes more per day or sometimes nothing, depending on my clients and what they can afford... I have a big sister who has a good job in N'Djamena but I cannot ask her help for personal reasons. Similarly, I do not have contact with my family in the village.

Nguéli negatively affects all its inhabitants' sources of livelihood. The opportunities are there but obstacles constantly impede people's efforts. Daily stress, violence and insecurity destroy their moral and physical strength and households are vulnerable at all levels, with the options that could provide food being speculative and risky. Constant military pressure suppresses initiative, reduces people's morale and increases feelings of uncertainty about the future, and mistrust and insecurity prevent economic and social development.

\section{Secteur 4 in Mongo}

The situation in N'Djamena's peripheral areas is not unique in Chad and smaller towns in the country's interior have populations with similar problems, as will be seen in the example of Mongo.

Mongo is the capital of the Guera Province in central Chad. It is the country's fifth largest town and has an estimated population of $27,000^{\mathrm{III}}$, $98 \%$ of whom are Muslim. The city is an administrative centre where the few international organisations active in the region have their offices and where the governor, the offices of the préfecture, various government services, the military, 
the gendarmerie, the hospital and the secondary school are housed in old buildings that remind the town of its colonial past. Mongo has an important regional market on Wednesdays but despite its shops, cattle market, Catholic mission, Protestant mission, two big mosques and numerous smaller ones, it is, in appearance and in reality, a poor town. However the different quarters do not experience this poverty to the same extent.

The town has attracted families and women with children who have fled their villages as a result of poverty, war-related violence and unrest, drought and bad harvests (De Bruijn et al., 2004). The town has always been a base for military reservists but because of the Darfur crisis the government has strategically deployed thousands of young soldiers there before sending them on to the east of the country (UNICEF, 2007). As a result, we found many child soldiers on Mongo's streets in 2007/2008, a situation that was increasingly worrying the local population, and nowadays even the international media are interested in the town. Mongo is not only a place of refuge for those in need or looking for employment. It is also attractive because of the provincial health centre.

During the droughts of the 1980s, many rural people took refuge in Mongo because of the humanitarian aid available there. To organize the distribution of food then, the city was divided into nine sectors. Secteur 4, where we did our research, is on the outskirts of Mongo and its name has stuck. It is Mongo's poorest neighbourhood and its inhabitants are mostly 'crisis' migrants.

At first sight, Secteur 4 has the appearance of a disorganised dusty village. Huts are made of mud bricks, straw and millet stalks, and are scattered at the foot of a mountain. Household equipment in the huts is minimal, there are no latrines and water comes from wells outside Mongo. The small paths people walk along to go from their huts to the bush every morning before sunrise are the only permanent form of infrastructure. A few goats nibble at the huts and chickens pick at the plants. Trees are scarce. This sector has no school or other governmentrelated services. The better houses are the ones belonging to a Malian immigrant whose father was an ancien combattant and those of a few civil servants and the widows of rich traders.

It seems that before 1979 this part of Mongo was a green space with many trees but soldiers of the regular army destroyed them. Indeed, when the civil war started in 1979, the rebellion leaders of that day, CDR, established their headquarters at the Protestant Barbassa Mission, an area close to Secteur 4. To ensure a clear view of the rebels' route, they cut down all the trees nearby (De Bruijn, 2006), men were butchered or hanged by the rebels and women and children were abused, tortured and dispossessed of their property. After the fall of the CDR, the area became an open space and was used for humanitarian aid purposes. During the drought of the 1980s, villagers settled here to receive food and care and later other people from the villages joined them. Others who moved to Secteur 4 had already lived in one of Mongo's better-off quarters but had had to sell their land and house to be able to pay hospital bills or feed their family.

Secteur 4 became a gathering point for very poor people and the majority are now regarded as disadvantaged (widows, the blind, lepers, etc.). The dates when the 48 households in our sample settled in Secteur 4 are as follows: 14\% between 1960 and 1979; 59\% between 1980 
and 1990; and 27\% between 1991 and 2003. Of the 48 households, 42 were female headed (24 were widows and 18 were divorced).

We reconstructed the occupation history of the area with the help of information gained in these interviews. Of the 48 women in our sample, 24 had arrived in Secteur 4 at a time of drought, 11 because of various different problems (witchcraft, theft, rape, adultery), eight due to the war and rebel activity, and five had no specific reasons but social and economic pressures are a plausible explanation. The life stories of most of them reveal the multiplicity of their reasons for being in Secteur 4, and for staying there. Drought is related to hunger and one woman explicitly said, 'If I had stayed in my village I would have died of famine like the others'. The results of that famine were also devastating because of the long civil war. Five of the residents, three elderly ladies and two women of about 40 years of age, recounted the story of the IDP camp that was set up in Barbaza/Secteur 4 in the 1980s when the Guera was experiencing hard times after the outbreak of violence and drought. As a result of the war, the country's infrastructure was very bad and NGOs had little or no access to people living in the countryside. The Red Cross and the World Food Program were the first international aid organisations to arrive in Mongo to help the local people, among them the women cited above who see themselves as 'refugees'. The Red Cross did not stay in the area for very long but after they left, the people they had attracted to Mongo did not leave Secteur 4. One woman told us she could buy land there for FCFA 1500 and another said that land was available in that part of town as it was considered bush.

Malnutrition is almost endemic in Secteur 4. Children are born and grow up in conditions of famine and the infant mortality rate is $47 \%$. Of the 42 children between 6 and 59 months in our sample, 40 were affected by acute malnutrition with an average weight for height $\mathrm{Z}$-score below -3 and 38 suffered from chronic malnutrition (stunting). The health of their mothers was similarly poor: the average BMI was $16.7 \mathrm{~kg} / \mathrm{m}^{2}$, below the normal BMI of $18.5 \mathrm{~kg} / \mathrm{m}^{2}$. We cannot talk here about the frequency of meals in households as it is very difficult to access food. Meals are usually of sorghum with different sauces, locusts being the main source of protein in all households. None of the 48 households expected to experience food security and it is a constant battle for them to acquire food. When we did the interviews, nobody had a stock of cereal. It is a context of endemic poverty devoid of hope. Health and education are not priorities for $89 \%$ of households, and others see these services a being for 'the rich and people who eat well'.

All Secteur 4 household members are involved in the daily search for food, including children and the infirm and disabled who beg near the mosque and the markets. Nobody has a stable source of income. In 39 of the households, at least one member begs. For the people in Secteur 4 this has become an important aspect of their daily existence. Old women, some of whom are blind, beg on Fridays at the mosques and some on Sundays outside the churches. They roam through town during the week going to the market and from house to house, receiving a substantial part of their family's food from others. They were always happy to show us the results of their begging activities. Religious festivals, Friday prayers and ceremonies (weddings, funerals, baptisms and circumcisions) offer opportunities to eat meat and have meals. 
All consider their lives hard but are accepting. 'Isn't life in the village worse?' Many have health problems but no means of paying for treatment. They all have to care for their children, either their own or those of their deceased children or those who have migrated. The advantage of living in this area is that land is free and there are active social networks. Agriculture is the only activity that can generate income for households but the poor soil needs to be fertilized, which discourages many. Even though life is hard, people find a way to survive. Their life histories show how they have responded to the difficulties they face:

Three years ago I stopped working my own field, I do not have the strength needed on an empty stomach so I tried to gather food in the bush hoping to find something to feed my family, but there was nothing satisfactory. It is always a failure, many people here in Secteur 4 prefer to beg or work for other people in town. If you are blind or a leper, begging works and people might give you something out of pity. Manual labour is a good alternative but many people around Mongo pay according to their harvest, and the amount is never certain. I prefer cash. It is also difficult to find this kind of work. Thankfully last year I had work in the Arabs' fields, and this has enabled me to earn 20 coros of red sorghum and FCFA 5000. I hope to find the same work this year. Who knows what will happen in the future? In Chad tomorrow does not belong to anyone.

Bozile Soumaine 55 years old, Secteur 4, October 2005

People are forced by different forms of violence (physical or moral) to live in misery. At the administrative level in Mongo, no attention is being paid to this situation although there are a few private organizations that provide support in individual cases, a good example being the Protestant mission that cares for lepers and blind children. Some Islamic organizations also provide help, and increasingly people are converting to Islam to receive assistance in alleviating their suffering. Secteur 4 is a benchmark of social exclusion: it is the place where all the unfortunate and unlucky people from the villages and the city are concentrated. Cultivation could be the ideal method of food security but the land has been depleted.

Support networks can be based on matrial support and on moral support as well. As Platteau (1991) indicated, a support network without material wealth at its basis is bound to fall apart. He introduced the idea of co-variance of risk. Our data however show that moral support alone can make a difference for survival. Interviews and observations show that neighbours in this area do try to help each other in both ways. Support networks often involve immediate neighbours but are usually made up of children or family members. The people share the same lives, and sharing problems helps make life bearable. Such relations may also be $a d$ hoc as new people arrive and others move out. Their existence became clear to us when a person died and the women all visited her house, or when a baby was born and everyone came with small gifts. Secteur 4 in this sense has become a social neighbourhood and this sociality is not primarily linked to ethnicity or village relations but rather to the sharing of a similar life and, of course, being a family. In two cases, sisters lived together. In another case, a woman lived with her brother who owns one of the big farms. Her story however shows that caring for another person is a limited affair and that it is finally the individual who has to take care of him/herself. 
Table 1: Socio-demographic, nutritional and health characteristics of the three study areas

\begin{tabular}{|l|c|c|c|}
\hline \multirow{2}{*}{} & \multicolumn{2}{|c|}{ N'Djamena } & Mongo \\
\cline { 2 - 4 } & Diguel & Nguéli & Secteur 4 \\
$\mathrm{~N}_{\mathrm{h}}=33 / \mathrm{Nc}=36$ & $\mathrm{~N}_{\mathrm{h}}=30 / \mathrm{Nc}=40$ & $\mathrm{~N}_{\mathrm{h}}=48 / \mathrm{Nc}=42$ \\
\hline Characteristics of households & & & \\
Percentage of Educated householders & 18 & 36 & 20 \\
Percentage of Female head householders & 45 & 40 & 87 \\
Average of dependants & $4 \pm 1.5$ & $4.5 \pm 1.6$ & $3.2 \pm 1.4$ \\
Average age of household head & $26 \pm 7$ & $29 \pm 8$ & $33 \pm 12$ \\
\hline Health and nutritional status & & & \\
Percentage of wasted children & 61 & 60 & 95 \\
Percent of stunted children & 47 & 33 & 60 \\
Child mortality rate & 19 & 44 & None \\
Percentage of immunized Children & $9.97 \pm 1.64$ & $11.14 \pm 1.50$ & nd \\
Average value of Mothers' haemoglobin & $17.02 \pm 2.32$ & $18.06 \pm 2.70$ & $16.70 \pm 2.80$ \\
Average value of Mothers' BMI & & 43 & None \\
\hline Living conditions & 3 & 6 & None \\
Percentage of households with drinking & $100($ Temporary) & 12 & None \\
water & 18 & 60 & None \\
Access to healthcare and education & 74 & all & all \\
Secure employment & all & 67 & all \\
Fear of losing land/house & 72 & 1,9 & \\
Psychological pressure & 1,3 & & \\
Percentage of food insecure households & & & \\
Number of daily meals & &
\end{tabular}

$\$ N b=$ Number of Households, Nc $=$ Number of children under five.

The previous table summarises some of the results from the three study areas.

\section{Discussion}

What can we learn from the cases presented above? The pictures we drew illustrate survival in three urban districts in Chad and reveal the lives of_neglected victims of humanitarian crises. To understand the daily lives of these people and their basic social organisations, we needed information about the historical and current factors influencing their socio-economic networks, their physical and moral integrity and the way these have contributed to the obstacles that prevent secure livelihoods. We combined quantitative and qualitative methods to try to establish the picture of the living conditions and livelihoods of households and individuals in these communities.

Both our qualitative and quantitative data led to a better understanding of the interaction between individuals and their social context. As Sen (1983) put it: 'A person's ability to command - indeed, to command any commodity he wishes to acquire or retain - depends on the entitlement relations that govern possession and use in that society. It depends on what he owns, the kind of exchange possibilities offered to him, what is given to him free, and what is taken away from him.' Any disturbance at this level is fatal to the stability of society and households: the dynamics of society can be affected. The emergence of tensions, alienation, violence, restrictions or a decrease in social relationships, as we observed in these neighbourhoods, constitutes a response to this level of disturbance. The pressure of public power, structural violence and inequality in N'Djamena does not allow these migrants in Diguel, and especially in Nguéli, to access the survival opportunities that are potentially available to them but are not accessible. All the forms of negotiation these people initiate depend on a certain bargaining power and in these highly social but fundamentally poor contexts bargaining power constitutes an equivalent 
to purchasing power in a context in which monetary assets are more available. Sometimes these people are forced to make sacrifices and, in order to survive, some migrants adopt habits and behaviour that are fundamentally opposed to or at least incongruent with their norms and values (e.g. religion). They thus live in constant fear of being rejected by their own communities. Likewise, to obtain certain employment (for example as a guard), people may be obliged by their future employer to convert to Islam. Another example is the case of adolescents who engage in prostitution or join criminal networks to help their families. These forced changes in behaviour are a response to high levels of insecurity and underline the fact that 'food insecurity integrates the ability to acquire adequate food personally by socially acceptable ways is limited or uncertain' (Allen, 1999; see also Radimer et al., 1992).

The quantitative data acquired enabled us to gain insight into the physical expression of the difficulties experienced individually and collectively (e.g. at household level). Such data included information on the nutritional status and health of mothers and children under five and infant mortality rates. In all three squatter areas, the rates of child malnutrition and mortality point to a humanitarian crisis. The combination of inadequate and insufficient food and illness damages people's physical and physiological capacity, with serious consequences for the wellbeing of their families and the entire society. As studies have shown, malnutrition is a major cause of brain damage, low birth weight, mortality and birth defects, which contribute to physical and cognitive under-development, mental retardation and susceptibility to infectious disease in the long term (Finch \& Crimmins, 2004). These consequences negatively influence individuals' physical abilities and intellectual potential.

Most of the people we spoke to had been traumatized in some way and new generations are growing up and continuing to live in a society still marked by famine, violence and social disruption.

\section{Conclusion}

The difficult situations in which people live in the margins of Chad's urban areas made us wonder whether these areas are considered as an opportunity or a refuge by socially excluded groups. To what extent is the choice to move to town a part of people's decision making in their own lives? They are both victims and active participants in the problematic circumstances in which their lives develop. The majority of the migrants in N'Djamena are poor Hadjaray who live in groups according to ethnic origin. These social clusters provide protection and encourage a social 'micro climate' that recreates, to some extent, their original village life. Social relationships generate the capacity to negotiate access to resources, assets and claims, including living space, and are a way of reconstituting cultural identity. This type of clustering is a survival strategy often used by poor people living in insecurity and instability (De Bruijn \& Van Dijk, 1995). The fact that they choose to occupy the peripheral areas of towns and cities gives them the opportunity to build up and reinforce mutual relationships and to generate assets that would otherwise be unavailable.

The victims of humanitarian crises in Chad in the past have been neglected both by the Chadian government and by international organisations. Some of the specific interventions provid- 
ing international medical and technical assistance as well as food aid were helpful for the immediate victims of acute crises. However assistance did not reach people equally nor did it always arrive at the appropriate time or reach those who were most in need or living outside certain selected zones. Once a crisis situation has become endemic and detached from the event that triggered it, the populations affected are frequently abandoned, leaving victims living in fear in situations of misery and extreme poverty as we saw in Mongo's Secteur 4.

The Darfur crisis is currently attracting different (international) groups offering humanitarian assistance that is being brought to the refugee camps in eastern Chad from N'Djamena. Aid convoys have to cross parts of Chad where life is miserable and people are experiencing conditions not unlike those in the refugee camps themselves. These neglected people who are struggling to survive in communities beside the roads along which the humanitarian convoys rush en route to eastern Chad are receiving no attention and have no voice.

\section{References}

ALLEN, P. 1999. Reweaving the food security safety net: Mediating entitlement and entrepreneurship. Agriculture and Human Values, 16(2):117-129.

AZEVEDO, M.J. 1998. Roots of Violence: A History of War in Chad. Amsterdam: Gordon \& Breach.

CHAMBERS, R. \& CONWAY, G. 1992. Sustainable rural livelihoods: practical concepts for the 21st century. IDS Discussion Paper 296, Brighton: Institute of Development Studies

DE BRUIJN, M. 2007. Agency in and from the margins: Street children and youth in N'Djaména, Chad. (In De Bruijn, M., Van Dijk, R. \& Gewald, J.B. eds. Strength beyond Structure: Social and Historical Trajectories of Agency in Africa (Leiden: Brill, p. 263-285. )

DE BRUIJN, M. \& DJINDIL, N.S. 2006. État Nutritionnel et histoire de vie des 'enfants de la rue' à N'Djamena. Psychopathologie africaine 33(2):183-211.

DE BRUIJN, M \& VAN DIJK, H. 1995. Arid Ways: Cultural Understandings of Insecurity in Fulbe Society, Central Mali. Wageningen: CERES.

DE BRUIJN, M \& VAN DIJK, H. 2007a. Chad. (In Mehler, A., Melber, H. \& Van Walraven, K. eds. Africa Yearbook: Politics, Economy and Society South of the Sahara in 2006 Leiden: Brill Academic Publishers. p. 215-223.)

DE BRUIJN, M \& VAN DIJK, H. 2007b. The multiple experiences of civil war in the Guéra region of Chad, 1965-1990. Sociologus, 57(1):61-98.

DE BRUIJN, M \& VAN DIJK, H. 2008. Chad. (In Mehler, A., Melber, H. \& Van Walraven, K. eds. Africa Yearbook: Politics, Economy and Society South of the Sahara in 2007 Leiden: Brill. p. 223-230.) 
DE BRUIJN, M \& VAN DIJK, R. 2007. Introduction. (In De Bruijn, M., Van Dijk, R. \& Gewald, J.B. eds. Strength beyond Structure: Social and Historical Trajectories of Agency in Africa, Leiden: Brill, p 1-13.)

DEVEREUX, S. 2001. Livelihood insecurity and social protection: A re-emerging issue in rural development. Development Policy Review, 19(4):507-520.

DICKOW, H. 2005. Democrats without Democracy?: Attitudes and Opinions on Society, Religion and Politics in Chad. Byblos: Centre International des Sciences de l'Homme.

DJINDIL, N.S., TABO, S.N \& MOGOTA, A.T. 2007. Who benefits from public social spending in Chad? A benefit incidence analysis. PEP PMMA Working Paper 2007-11. [Web:] http://ssrn.com/abstract=975219. [Date of access:] 8 June 2009.

ESSED, P.H., FRERKS, G. \& SCHRIJVERS, J. 2005. Refugees and the Transformation of Societies, Agency, Policies, Ethics and Politics. New York/Oxford: Berghahn Books.

ERIKSSON, H. \& HAGSTRÖMER, B. 2005. Chad: Towards Democratization or Petro-dictatorship? Uppsala: Nordic Africa Institute.

FAO see UNITED NATIONS: FOOD AND AGRICULTURE

FINCH C.E. \& CRIMMINS, E.M. 2004. Inflamatory exposure and historical changes in human lifespans. Science, 305(5691):1736-1739.

INTERNATIONAL CRISIS GROUP (ICG). 2006. Tchad: Vers le retour de la Guerre? Africa Report 111, 01-06-2006. [Web:] http://www.unhcr.org/refworld/docid/44c77d614.html [Date of access:] 8 June 2009.

GALLAIS, J. 1975. Pasteurs et paysans du Gourma : la condition sahelienne. Paris : C.N.R.S. (18):1233-239.

MILES, W.F.S. 1995. Tragic tradeoffs: Democracy and security in Chad. The Journal of Modern African Studies, 33(1):53-65.

\section{OECD see ORGANISATION FOR ECONOMIC CO-OPERATNIO AND DEVELOPMENT}

ORGANISATION FOR ECONOMIC CO-OPERATION AND DEVELOPMENT. 2007. Chad: Perspectives économiques en Afrique 2007. Pp 181-195.

PLATTEAU, J.P. 1991. Traditional system of social security and hunger insurance: Past achievements and modern challenges. (In Ahmad, E., Drèze, J., Hills, J. \& Sen, A.K. eds. Social Security in Developing Countries. Oxford: Clarendon Press. p. 112-170.)

RADIMER. K.L., OLSON, C.M., GREENE, J.C., CAMPBELL, C.C., \& HABICHT, J.P. 1992. Understanding hunger and developing indicators to assess it in women and children. The Journal of Nutrition Education, 24(1):36-45.

RIBOT, J.C. \& PELUSO, N.L. 2003. A theory of access. Rural Sociology, 68(1):153-181.

SEN, A. 1983. Poverty and Famines: An Essay on Entitlement and Deprivation. Oxford: Oxford University Press.

\section{UNDP see UNITED NATIONS DEVELOPMENT PROGRAM}

UNICEF see UNITED NATIONS CHILDREN'S FUND

UNITED NATIONS CHILDREN'S FUND. 2007. Central African Republic signed child soldier reintegration agreement. Press note, 16 June 2007. [Web:] http://www.unicef.org/infobycountry/me- 
dia_40015.html._[Date of access:] 8 June 2009.

UNITED NATIONS DEVELOPMENT PROGRAM. 1990-2008. Human Development Reports from 2000-2008. [Web:] http://hdr.undp.org/en/reports. [Date of access:] 8 June 2009.

UNITED NATIONS: FOOD AND AGRICULTURE. 1996. World Food Summit - Rome Declaration on World Food Security and WFS Plan of Action. WFS document. Rome, FAO.

USAID. 2008. Chad: Complex Emergency. Situation Report 2. [Web:] http://www.usaid.gov/our_ work/humanitarian_assistance/disaster_assistance/countries/chad/template/fs_sr/fy2008/chad_ce_ sr02_06-27-2008.pdf. [Date of access:] 8 June 2009.

VAN DIJK, H. 2007. Briefing: Political deadlock in Chad. African Affairs, 106 (425): 697-703.

WGI see WORLDWIDE GOVERNANCE INDICATORS

WHO see WORLD HEALTH ORGANISATION

WORLD HEALTH ORGANISATION. 1995. Physical status: The use and interpretation of anthropometry. World Health Organisation, Technical Report Series.

WORLDWIDE GOVERNANCE INDICATORS. 2008. Country data report for Chad, 1996-2007. Governance Matters. [Web:] http://info.worldbank.org/governance/wgi/pdf/c211.pdf. [Date of access:] 8 June 2009.

\section{Notes}

I. Gombo name for Okra

II. Bogo-bogo: Customs officer in charge of combating fraud. Karan-Karan: refers to fortyforty the number plate of customs' vehicles. Both have the connotation of corrupt officials because they usually abuse the population

III. See the web site for this estimation: www.tageo.com/index-e-cd-cities-TD-lg-fr.htm 